\title{
Whipple disease
}

INSERM

\section{Source}

INSERM. (1999). Orphanet: an online rare disease and orphan drug data base. Whipple disease. ORPHA:3452

Whipple's disease (WD) is a chronic infectious disorder in which almost all org an systems can be invaded by the rod-shaped bacterium Tropheryma whipplei (T . whipplei). 